\title{
Perception on the Quality of Life of Elderly People during COVID-19 Pandemic in Chile
}

\author{
Alejandro Almonacid-Fierro ${ }^{1}$, Rodrigo Vargas-Vitoria ${ }^{1, *}$, Manuel Almonacid ${ }^{2}$, Miguel Martínez ${ }^{3}$ \\ ${ }^{1}$ Faculty of Education, Universidad Católica del Maule, Talca, Chile \\ ${ }^{2}$ Faculty of Education, Universidad Autónoma de Chile, Talca, Chile \\ ${ }^{3}$ Faculty of Psychology, Universidad de Talca, Chile
}

Received February 15, 2021; Revised March 16, 2021; Accepted April 22, 2021

\section{Cite This Paper in the following Citation Styles}

(a): [1] Alejandro Almonacid-Fierro, Rodrigo Vargas-Vitoria, Manuel Almonacid, Miguel Martínez, "Perception on the Quality of Life of Elderly People during COVID-19 Pandemic in Chile," International Journal of Human Movement and Sports Sciences, Vol. 9, No. 3, pp. 473 - 479, 2021. DOI: 10.13189/saj.2021.090312.

(b): Alejandro Almonacid-Fierro, Rodrigo Vargas-Vitoria, Manuel Almonacid, Miguel Martínez (2021). Perception on the Quality of Life of Elderly People during COVID-19 Pandemic in Chile. International Journal of Human Movement and Sports Sciences, 9(3), 473 - 479. DOI: 10.13189/saj.2021.090312.

Copyright $\bigcirc 2021$ by authors, all rights reserved. Authors agree that this article remains permanently open access under the terms of the Creative Commons Attribution License 4.0 International License

\begin{abstract}
This article aims to investigate the perception of the quality of life of the elderly as a consequence of the COVID-19 pandemic that has been affecting the world since December 2019, and that as of January 2021 records more than 100 million cases worldwide. The most affected population has turned out to be the elderly with chronic diseases and those with organic dysfunctions, product of physiological changes that are expressed with old age. The study is framed in the interpretative-comprehensive paradigm, with a qualitative methodology, considering the realization of 17 semi-structured interviews to older adults who participated in sports-recreational workshops offered by the National Institute of Sports in the region of Maule, Chile. The interviews were conducted during the months of July and September 2020 and were carried out via Skype or video call, in order to maintain the distance and respect the measures established by the health authority in Chile. As for the results, the affectation of the quality of life of older adults, who have not been able to perform regular physical activity during the months of the pandemic, added to the adverse psychological effects of confinement and social isolation, which has prevented them from having direct and face-to-face contact with their loved ones, is evident.
\end{abstract}

Keywords Pandemic, COVID-19, Elderly, Quality of Life

\section{Introduction}

During the recent months, the world has witnessed the evolution of an infectious pandemic called Coronavirus Disease (COVID-19) whose an etiological agent is the severe acute respiratory syndrome coronavirus (SARS-CoV-2) [1]. COVID 19 has been defined as a set of acute respiratory disease, which is transmitted from person to person through contact with infected secretions, mainly through contact with large respiratory droplets [2]. In this sense, it is necessary to examine the impact of the COVID-19 pandemic on the quality of life of elderly adults as a comprehensive health criterion, since in 2020, there are 1.1 billion of elderly people in the world, with a projection of 3.1 billion in 2100 , which converges with the Chilean scenario. In Chile, according to the National Service for the Elderly (SENAMA), there are 2.6 million people over 60 years of age, $15.6 \%$ of the population and by 2025 the population over 60 is expected to constitute $20 \%$, which will exceed the percentage of population under 15 years of age [3]. The foregoing establishes a shared concern for this age group that is sharply increasing on the national and global level and that demands a health system that can address the aging population [4].

The elderly stand out in the Covid-19 pandemic, largely due to the changes resulting from senescence and senility [5]. Despite the aging population, unfortunately there is little visibility and appreciation for this portion of the population. The Covid-19 pandemic has highlighted the 
elderly population, mainly due to the potential risk to this group, with actions and strategies of social distancing, specifically aimed at this group. For elderly people, practicing physical exercises acts as a beneficial measure for the improving immunity in the prevention and adjunctive treatment of chronic diseases and viral infections such as the new coronavirus. The protective effect of exercise on the immune system is crucial, to respond adequately to the threat of Covid-19 [6], consequently, regular practice of physical exercise improves the quality of life of the elderly in during the Covid-19 pandemic.

During this pandemic, older people have shown other characteristics, in addition to the peculiarities of human aging [7]. In this scenario, despite epidemiology, virology, immunology and many other necessary and recurring fundamental concepts, one cannot ignore the fundamentals of gerontological theory and practice, which promote the differential for the adoption of effective measures in the protection of the risk of the elderly [8]. Social isolation indicates the need to (re)configuring behaviors, prioritizing actions of consistent hygiene such as hand washing, use of hand sanitizer, distancing from other people, environmental and emotional care. Meanwhile, family and the society can become a support system for the elderly, with actions infused with respect, truth, information and a set of daily activities to support the elderly, as reported in the literature of the following studies [9-12]. To age successfully, in addition to stimulating good physical and mental functioning, it is necessary that social activities are present [13-15]. Several studies have suggested that elderly people tend to associate their quality of life with the following aspects: the practice of physical exercise, access to leisure, carrying out intellectual activities and in particular, living with family, community and society [16-18]. On the other hand, interpersonal relationships play an extremely beneficial role in the quality of life for the elderly, both family ties and old relationships, as well as those new friendships built within community groups. Taking into account that the elderly population has the highest COVID-19 morality rate, it is important and extremely necessary to assess the impact of the virus on the quality of life of the elderly population [19].

Quality of life in regards to health represents the way in which elderly people perceive their health, translating the subjective well-being of the individual into several domains, mainly physical ability to perform tasks, psychological referring to emotional and mental well-being and social, the ability to relate to people $[20,21,18]$. The quality of life of the elderly is related the autonomy of daily activities and entertainment, satisfaction of the present and future, social interaction and how well they are mentally with themselves $[22,23]$. In this context, studying how COVID-19 pandemic has affected the elderly's quality of life and regular physical exercise practice becomes a challenge, since they are determining factors for maintaining an active and health state of health. Consequently, it is considered vitally important to know and understand the perception of the elderly regarding their quality of life during COVID-19 pandemic, on the understanding that it has been a difficult and complex time, particularly for the elderly.

\section{Materials and Methods}

\subsection{Research Design}

This work is a phenomenological inspirational study, within the interpretative paradigm framework, which uses qualitative methodology, since it aims to understand, describe and analyze the perceptions of elderly people during the Covid-19 pandemic [24,25].

\subsection{Research Instrument and Subject}

17 semi-structured interviews with elderly adults were performed, considering the following criteria: men and women over 65 years old are interested in participating in the study, signing informed consent; having participated in 2019 in a sports-recreational workshop funded by the National Sport Institute (NSI) in the Maule region, Chile; in 2020 they have enrolled in the aforementioned workshop and are physically and cognitively self-reliant people. The exclusion criteria were elderly adults under 65 years old and did not participate in the 2019 NSI program for the elderly.

\subsection{Data Collection}

Data from this study were collected during 2020, in the period of July-September and before the data collection, researcher obtained a written constant form to ensure the confidentiality of people's names, taking into account privacy and emphasizing voluntary participation. The participants were informed about the purposes of the research and their permission was requested to record the interview in order to safeguard the ethical aspects of the study according to the Declaration of Helsinki. The interview was performed via Skype and video call, due to the health emergency facing the country, and had an average duration of 60 minutes.

\subsection{Data Analysis}

For the data treatment, a content analysis [26] has been chosen that comprises three activity flows: data condensation, presentation and processing/verification conclusions. The data was analyzed using the inductive logic of theoretical categorization, which is based on the categorization as the main data analytical tool intended to theorize through operations leading to the theoretical 
construction [27], this process was assisted by the Nvivo 10 program.

\section{Results and Discussion}

Below (Table $\mathrm{N}^{\circ} 2$ ), dimensions, category, descriptor that emerged from the analysis and interpretation of the collected history from 17 interviews with elderly adults is presented.

The data from primary sources, that is, interviews were inductively analyzed with constant analysis and comparisons, which allows organizing and categorizing the data through content analysis. In this regard, an analysis was structured under a logic that initially defines the primary category, some stories from the primary documents are presented and then connect with some theoretical framework through critical reflection.

This section contains the description and interpretation of the categories and codes obtained from the analysis of the interviews are presented, as well as the units of analysis (which were taken from the reports), to account for the code and category obtained.

\subsection{Category: Impact of COVID-19 on Quality of Life - Secondary Category: Health Status}

The impact on the quality of life of the elderly as a result of Covid-19 pandemic is primarily associated with health status. This is manifested when the subjects investigated express the following:

"Of course that (the isolation) has been the greatest impact, but for the greater good of the health of us elderly people, in my case, I am more immobilized, and my health is not the same as a year ago, I am with pain that I did not have before" (S-4).

"The main objective is to exercise for our health, first of all, it is how we feel and what happens to our body, what happens is that we must stay between four walls, we do not exercise and it weakens our health." (S-5).

The population of over 65 years old has a higher probability of suffering from chronic diseases, being able to develop a severe picture of Covid-19 disease than other groups [8]. Faced with the complexity of the human aging process, with its own peculiarities combined with the high incidence of chronic diseases and their impact on the human body, it is evident for the need of specific care for the elderly, including prevention treatment and rehabilitation, in order to maintain adequate health [28]. From the literature $[18,29]$, healthy aging is considered to result from a multidimensional interaction between physical and mental health, independence in daily life, social integration, family support, and financial independence. Consequently, the evaluation of the quality of life is an important indicator of the perception that an elderly person has about their health status, as shown by the reports of the research participants.

Table 1. Data Systematization Matrix

\begin{tabular}{|c|c|c|c|}
\hline Category & First Sub-Category & Descriptor & Secondary Sub-Category \\
\hline \multirow{6}{*}{$\begin{array}{l}\text { Quality of life in elderly } \\
\text { adults during COVID-19 } \\
\text { Pandemic }\end{array}$} & \multirow{3}{*}{$\begin{array}{l}\text { Impact of Covid-19 on quality of } \\
\text { life }\end{array}$} & \multirow{3}{*}{$\begin{array}{l}\text { Refers to the pandemic's impact on the } \\
\text { quality of life of elderly adults. }\end{array}$} & Health status \\
\hline & & & Nutrition \\
\hline & & & Confinement \\
\hline & \multirow{3}{*}{$\begin{array}{l}\text { Psychological } \\
\text { Covid-19 }\end{array}$} & \multirow{3}{*}{$\begin{array}{l}\text { Refers to the pandemic's psychological } \\
\text { impact on elderly adults. }\end{array}$} & Emotional well-being \\
\hline & & & Different emotions \\
\hline & & & Feeling of loneliness \\
\hline
\end{tabular}




\subsection{Category: Impact of COVID-19 on Quality of Life - Secondary Category: Nutrition}

The quality of life of elderly adults is affected, among other issues, eating habits, and in this sense, it is known how elderly adults have assumed it, an issue that is manifested in the following stories:

"In regards to nutrition during the pandemic, I try to take care of myself as much as I can, with my medications and eating small amounts of salt and sugar, consuming water, fluids and exercising, which is the main thing because one has to try to move more and eat more vegetables and those things" (S-7).

"As for nutrition, we are organized and eat varied things, with a variety of fruits and vegetables, and what is bad, is eliminated as excess fat, but we do not have a major strategy, no one advises us, such as on meal times, taking medicine at the right time, sometimes I mess up a little," (S-10).

In the report given by the interviewees, it is reflected that elderly adults in the study have tried to maintain healthy eating habits, on the understanding that the quality of life is affect by how one eats. The high prevalence of nutritional aspects in the elderly population has been demonstrated by different studies, in which malnutrition, overweight and obesity are predominate risk factors. These results are due to the peculiar conditions in which the elderly find themselves, whether in the family environment, living alone or in a nursing home, exacerbated by socio-economic conditions, physiological alterations inherent to age and progressive inability to perform their daily activities alone $[14,30]$. In this context, the effects of dietary habits have an effect on the quality of life of elderly people, particularly during the Covid-19 pandemic.

\subsection{Category: Impact of COVID-19 on Quality of Life - Secondary Category: Confinement}

One of the most noted characteristic aspects of the Covid-19 pandemic is related to confinement, a measure that the World Health Organization adopted in order to prevent the spread of the virus.

"My life has changed being enclosed, being shut in is the same as someone that stresses you a bit, the frustration of not being able to go out, because you are enclosed, you cannot practice sports, although I can do it at home, but were are used to participating in the workshop as a group and now we have been home for months" (S-6).

"My opinion is fear, first, the fear of getting infected and also that it has complicated our lives, our existence, because we have to be shut in, not being able to visit with family, everything that happened before cannot be down now, the approach, affection with family, grandchildren and friends" (S-7).
The COVID-19 pandemic has highlighted the elderly, mainly due to the potential risk to this population, with actions and social distancing strategies specifically targeting at this group [11]. This situation also affected family relationships, with intergenerational conflicts, mainly due to the measures taken by governments to impose social distancing. During the COVID-19 pandemic, physical withdrawal reflects an act of love, affection and consideration, in addition to it being a protection strategy. The idea of defining and defending that social distance does not characterize abandonment is currently emerging, each family together with the elderly, must reflect and discuss the most appropriate strategies for their context. According to Berg-Weger \& Morley [31], the moments of social distancing are precautionary measures for health, with the intention to preserve and protect the elderly during the pandemic, however, the autonomy and independence of the elderly are the foundations for healthy aging, therefore, the freedom to exercise them is necessary, starting with the family and the society as a whole.

\subsection{Category: Psychological Impact of Covid-19 - Secondary Category: Emotional Well-Being}

From a psychological point of view, the COVID-19 pandemic has heavily impacted the elderly population, as expressed in the reports of the subjects investigated:

"Because I like to be active, I like to share with people, I do not like loneliness, that is why one seeks to know more people, stay active, I love to participate in all things, one is to be more active, not to lose mobility, so all the activities we did in the workshop helped me improve emotionally" (S-8).

"I live in the country and went to classes at different clubs, I was very distracted, within just one hour I was distracted, and I had a great time. Before the pandemic, I practiced physical activity in all centers in Maule and Talca, I felt free, happy, problem free, so I'm looking forward to going back again, because I need to vent, to move my body and to relax my mind, because I'm old now and everything affects me emotionally" (S-9).

Social distancing, quarantine and isolation reduce the necessary incentives for people to develop their routine activities because of the sudden changes in the individuals' routine, which impacts their lives in some way, such as the fear of getting sick and death; changes in sleep, appearance of feelings of hopelessness, boredom, loneliness, anger, frustration or irritability due to the loss of autonomy and personal freedom [12]. The changes that occur with aging are not only related to one's physical issues, but also to psychological factors, such as stress, depression, emotional problems and difficulty socializing in accordance to what is stated by Pinazo-Hernandis [13]. Physical dependence makes the elderly feel undervalued which can lead to 
developing psychological problems. Consequently, it is important that the elderly stay in an occupation that interest them, that exercises their mind, since aging is a process that must be experienced with autonomy, recognition of rights, security, dignity, well-being and health, as expressed by the research subjects.

\subsection{Category: Psychological Impact of COVID-19- Secondary Category: Types of Emotions}

The realm of emotions has been particularly complex for the elderly during the COVID-19 pandemic, due to the effects of confinement, the news regarding the pandemic and uncertainty, as reflected in the following accounts:

"Regarding emotions, I felt a lot of anguish the first month, for example, it was like you felt you were already sick, one thought it was like the virus had already reached you, but I think it was more sentimental due to the fact that I was separated from one of my children, because I was use to my children coming over every day, I stopped seeing them from one day to the next." (S-7).

"During this time, people I've known have died and one has not been able to accompany the family and that hurts me, because those deaths affect me. As for the family, that affects us because we cannot hug them, which causes anguish, grief, a mixture of things and the only way I can deal with it is by taking care of my task at home." (S-8):

Social isolation is a situation that requires patience from everyone who is in this situation, the need for human confinement in the home environment, and as a result, situations of anxiety, stress, and anguish are common and are experienced by the elderly. The literature reports that the pandemic has generated a whirlwind of emotions linked to hopelessness, boredom, loneliness and depression due to isolation and on the other hand, anger, frustration or irritability due to the loss of autonomy and personal freedom, fear and sometimes a lot of anxiety [32.33]. Despite the negative consequences that the COVID-19 pandemic has caused in the elderly population, we can observe that human beings can find different ways to face these adversities. To overcome these existential adversities, it is possible to resort to hobbies, exercise, reading, movies, meditations, prayers, love practices, housework among other activities [12], allowing for the development of positive emotions during such complex times that we are living in.

\subsection{Category: Psychological Impact of COVID-19 - Secondary Category: Feeling of Loneliness}

The feeling of loneliness category emerges from the accounts told by the elderly interviewed as a way of showing how difficult it has been for them to live during the pandemic, with the sanitary restrictions that make them feel mostly alone, as expressed by the following stories:

"Everything changed, everything changed because practically if one goes out, one has to separate from the others, there is not the communication like there was before when we out on the street with a friend or neighbor, for fear of coming back infected, it changed everything, the family scheme, in every sense, because almost everyone lives in their room, because offear, it is like a new system, it is like learning to live again with an unknown disease” (S-5).

"Sad because the lonelier one is, it is better that they not get sick, I do not like it because I like to go for walks, thus one cannot enjoy life like that, I like to exercise, but I can't, the pandemic leads us to be alone all the time, without the company of those you want to be with" (S-9).

To understand the psychological repercussions of a pandemic, as in the case of COVID-19, it should be noted that some specific groups are especially vulnerable, such as the elderly, so the feelings such as fear, loneliness and even depression are considered and observed [34]. The practice of social isolation has caused much controversy throughout the world, however, it must be recognized that the process of social isolation s causing some impacts on the lives of elderly people. When the elderly have low social support and deteriorated family ties, social vulnerability arises, deteriorating psychological and functional health, which are exacerbated by confinement according to what was stated by Flett, \& Heisel [35] and Grossman et al. [36]. For the elderly, isolation can be more painful, weakening their ability to adapt and react, producing emotional responses as feelings of loneliness, which affect the mental balance, as evidenced in the reports of the subjects interviewed.

\section{Conclusions}

The aging population is one of the biggest challenges in contemporary public health, with this phenomenon being confirmed in developing countries, such as Chile, where the aged population there has been more pronounced in the last 20 years. In this regard, one should note that the need to describe and analyze the impact on the quality of life of elderly people who participate in regular physical activities, in times of COVID-19 pandemic has been the purpose of the present study, also considering the numerous benefits of regular physical activity, which helps maintain and improve the quality of life of elderly people, in terms of the nutrition and health of the elderly despite confinement as manifested in the reports described above.

For another perspective, it is essential that the experiences provided by this turbulent time of crisis strengthen and prepare society to provide care and 
attention to the elderly, through comprehensive strategies that consider physical, social and psychological aspects. The above, with the understanding that the elderly are part of the at risk group, therefore, elderly people are also more threatened by COVID-19 because of their care needs or because they live in high-risk environments. This is aggravated by social distancing measures, such a preventing family and friends from entering their homes, since during the pandemic the recommendations for social and home isolation following the guidelines by the WHO and scientific literature, this being an important measure to reduce the spread of COVID-19 within the elderly population, however according to the testimony of our interviewees, their emotional well-being has been affected as well as feelings of loneliness and abandonment.

\section{Acknowledgements}

The researchers express their appreciation to the older people who voluntarily participated in the study, without them, the investigation could not have been carried out. Their honesty and commitment were essential in the field work.

\section{Conflict of Interest}

None declared.

\section{REFERENCES}

[1] World Health Organization, "Novel Coronavirus (2019-nCoV) technical guidance", 2020.

[2] Bonanad, C, García-Blas S, Tarazona-Santabalbina FJ, Díez-Villanueva P, Ayesta A, Forés JS, Martínez-Sellés M, "Coronavirus: la emergencia geriátrica de 2020. Documento conjunto de la Sección de Cardiología Geriátrica de la Sociedad Española de Cardiología y la Sociedad Española de Geriatría y Gerontología", Revista Española de Cardiología, vol. 73, no. 7, pp. 569-576, 2020. https://doi.org/10.1016/j.recesp.2020.03.027

[3] Condeza AR, Bastías G, Valdivia G, Cheix C, Barrios X, Rojas R, Fernández F, "Adultos mayores en Chile: descripción de sus necesidades en comunicación en salud preventiva", Cuadernos. info, vol. 38, pp. 85-104, 2016. http://dx.doi.org/10.7764/cdi.38.964

[4] Lim WS, Wong SF, Leong I, Choo P, Pang WS, "Forging a frailty-ready healthcare system to meet population ageing", International journal of environmental research and public health, vol. 14, no. 12, pp. 1448, 2017. doi:10.3390/ijerph1 4121448 .

[5] Sannicandro I, Cofano G, Rosa RA, Colella D, "The sedentary contrast strategies in the older people during the spread of Covid 19: The Italian experience", Sport Science, vol. 14, no. 1, pp. 60-64, 2020. http://sposci.com/PDFS/BR

\section{1/04\%20CL\%2010\%20IS.pdf}

[6] Rodríguez M Á, Crespo I, Olmedillas H, "Ejercitarse en tiempos de la COVID- 19: ¿qué recomiendan hacer los expertos entre cuatro paredes?", Revista Española de Cardiología, vol, 73, no. 7, pp. 527-529, 2020. https://doi.org/10.1016/j.recesp.2020.04.002

[7] Rahman A, Jahan Y, "Defining a 'Risk Group'and Ageism in the Era of COVID-19", Journal of Loss and Trauma, vol. 25 , no. 8, pp. 631-634, 2020. https://doi.org/10.1080/15325 024.2020 .1757993

[8] Applegate WB, Ouslander JG, "COVID - 19 presents high risk to older persons", Journal of the American Geriatrics Society, vol. 68 no. 4, pp. 681, 2020. doi: 10.1111/jgs.16426

[9] Ayalon L, Chasteen A, Diehl M, Levy B, Neupert SD, Rothermund K, Wahl HW, "Aging in times of the COVID-19 pandemic: Avoiding ageism and fostering intergenerational solidarity", The Journals of Gerontology Series B, vol 75, no. 4, pp 1-4, 2020. https://doi.org/10.109 3/geronb/gbaa051

[10] Armitage, R, Nellums, L. B, "COVID-19 and the consequences of isolating the elderly", The Lancet Public Health, vol. 5 no. 5, pp. 256, 2020. https://doi.org/10.1016/ S2468-2667(20)30061-X

[11] Brooke J, Jackson D, "Older people and COVID - 19: Isolation, risk and ageism", Journal of Clinical Nursing, vol. 29, no. 13, pp. 2044-2046, 2020. https://doi.org/10.1111/jo cn. 15274

[12] Losada Baltar A, Jiménez-Gonzalo L, Gallego-Alberto L, Pedroso-Chaparro MD, Fernandes-Pires J, Márquez-Gonzál ez M, "We're staying at home Association of self perceptions of aging, personal and family resources and loneliness with psychological distress during the lock-down period of COVID-19", The Journals of Gerontology: Series B. vol. 76, no. 2, pp. 10-16, 2020. https://doi.org/10.1093/g eronb/gbaa048

[13] Pinazo-Hernandis S, "Impacto psicosocial de la COVID-19 en las personas mayores: problemas y retos", Revista Española de Geriatría y Gerontología, vol. 55, no. 5, pp. 249-252, 2020. https://doi.org/10.1016/j.regg.2020.05.006

[14] Tavares RE, Jesus MC, Machado DR, Braga VA, Tocantins FR. Merighi MA, "Envelhecimento saudável na perspectiva de idosos: Uma revisão integrativa", Rev Bras Geriatr Gerontol, vol. 20, no 6, pp. 878-889, 2017. DOI: $10.1590 / 1981-22562017020.170091$

[15] Nabofa E, Akarahl E, Angba T, Onohwosafe P, "Mental Wellbeing and Exercise Participation during COVID-19 Pandemic among Adult Residents of Nigeria's Niger Delta", International Journal of Human Movement and Sports Sciences, vol. 8, no. 6, pp. 534-542, 2020. DOI: 10.13189/saj.2020.080628.

[16] Netuveli G, Blane D, "Quality of life in older ages", British medical bulletin, vol. 85, no. 1, pp. 113-126, 2008. https://doi.org/10.1093/bmb/ldn003

[17] Forte R, Boreham CA, De Vito G, Pesce C, "Health and quality of life perception in older adults: the joint role of cognitive efficiency and functional mobility". International journal of environmental research and public health, vol. 12, no. 9 , pp. 11328-11344, 2015. https://doi.org/10.3390/ijerp 


\section{h120911328}

[18] Li CI, Lin CH, Lin WY, Liu CS, Chang CK, Meng NH, Lin $\mathrm{CC}$, "Successful aging defined by health-related quality of life and its determinants in community- dwelling elders", BMC public health, vol. 14, no. 1013, pp. 1-8, 2014. https://doi.org/10.1186/1471-2458-14-1013

[19] Ping W, Zheng J, Niu X, Guo C, Zhang J, Yang H, Shi Y, "Evaluation of health-related quality of life using EQ-5D in China during the COVID-19 pandemic", PloS one, vol. 15, no. 6 , e $0234850,2020$.

https://doi.org/10.1371/journal.pone.0234850

[20] De Mejía BE, Merchán ME, "Calidad de vida relacionada con la salud (CVRS) en adultos mayores de 60 años: una aproximación teórica”, Revista hacia la Promoción de la Salud, vol. 12, pp. 11-24, 2007.

https://www.redalyc.org/pdf/3091/309126689002.pdf

[21] Dunsky A, "The effect of balance and coordination exercises on quality of life in older adults: a mini-review", Frontiers in aging neuroscience, vol, 11, pp. 318-324, 2019. doi: 10.3389/fnagi.2019.00318

[22] Vanleerberghe P, De Witte N, Claes C, Schalock RL, Verté $\mathrm{D}$, "The quality of life of older people aging in place: a literature review", Quality of Life Research, vol. 26, no. 11, pp. 2899-2907, 2017. https://doi.org/10.1007/s11136-017-1 651-0

[23] Chou CH, Hwang CL, Wu YT, "Effect of exercise on physical function, daily living activities, and quality of life in the frail older adults: A meta-analysis", Archives of Physical Medicine and Rehabilitation, vol. 93, no. 2, pp. 237-244, 2012. https://doi.org/10.1016/j.apmr.2011.08.042

[24] Flick U, "An introduction to qualitative research", Sage Publications Limited, 2018.

[25] Bernard HR, Wutich A, Ryan GW, "Analyzing qualitative data: Systematic approaches”, SAGE publications, 2016.

[26] Graneheim UH, Lindgren BM, Lundman B, "Methodological challenges in qualitative content analysis: A discussion paper", Nurse education today, vol. 56, pp. 29-34, 2017. https://doi.org/10.1016/j.nedt.2017.06.002

[27] Given LM, (Ed.), "The Sage encyclopedia of qualitative research methods", Thousand Oaks, CA: SAGE Publications, 2008.

[28] Beard JR, Officer A, De Carvalho IA, Sadana R, Pot AM,
Michel JP, Thiyagarajan JA, "The World report on ageing and health: a policy framework for healthy ageing", The lancet, vol. 387, no. 10033, pp. 2145-2154, 2016. https://doi.org/10.1016/S0140-6736(15)00516-4

[29] Garcia-Molina A, Carbonell-Baeza A, Delgado-Fernández M, "Health benefits of physical activity in older people", Revista Internacional de Medicina y Ciencias de La Actividad Fisica y Del Deporte, vol. 10, no. 40, pp. 556-576, 2010. http://cdeporte.rediris.es/revista/re

[30] Shlisky J, Bloom DE, Beaudreault AR, Tucker KL, Keller $\mathrm{HH}$, Freund-Levi Y, Meydani SN, "Nutritional considerations for healthy aging and reduction in age-related chronic disease", Advances in Nutrition, vol, 8, no. 1, pp. 17-26, 2017. doi: 10.3945/an.116.013474

[31] Berg-Weger M, Morley JE, "Loneliness and social isolation in older adults during the Covid-19 pandemic: Implications for gerontological social work", J Nutr Health Aging, Vol. 24 , no. 5, pp.456-458, 2020. https://doi.org/10.1007/s12603 $-020-1366-8$

[32] Viana SA, de Lima Silva M, de Lima PT, "Impacto na saúde mental do idoso durante o período de isolamento social em virtude da disseminação da doença COVID-19: uma revisão literaria", Diálogos em Saúde, vol. 3, no 1, pp. 1-8, 2020. https://periodicos.iesp.edu.br/index.php/dialogosemsaude/ar ticle/view/272

[33] Van Tilburg TG, Steinmetz S, Stolte E, van der Roest H, de Vries DH, "Loneliness and mental health during the COVID-19 pandemic: A study among Dutch older adults", The Journals of Gerontology: Series B, vol. 75, no. 5, pp. 1-7, 2020. https://doi.org/10.1093/geronb/gbaa111

[34] Ornell F, Schuch J, Sordi A, Kessler F, "Pandemia de medo e COVID-19: impacto na saúde mental e possíveis estratégicas", Revista debates in psychiatry, vol.10, no. 2, pp. 12-16, 2020. https://www.abp.org.br/rdp2020

[35] Flett GL, Heisel MJ, "Aging and feeling valued versus expendable during the COVID-19 pandemic and beyond: A review and commentary of why mattering is fundamental to the health and well-being of older adults", International Journal of Mental Health and Addiction, vol. 18, no. 3, pp. 1-27, 2020. https://doi.org/10.1007/s11469-020-00339-4

[36] Grossman ES, Hoffman YS, Palgi Y, Shrira A, "COVID-19 related loneliness and sleep problems in older adults: Worries and resilience as potential moderators", Personality and individual differences, vol. 168, no. 1, pp. 110371, 2020. https://doi.org/10.1016/j.paid.2020.110371 